\title{
Karakterisasi Feed Zone dan Potensi Produksi Sumur Panas Bumi ML-XX Muara Laboh, Solok Selatan
}

\author{
Devi Marisa D.P*1, Ardian Putra ${ }^{1}$, Robi Irsamukhti², Rudy Martikno ${ }^{2}$, Jantiur \\ Situmorang $^{2}$, Alfianto Perdana Putra ${ }^{2}$, Muhammad Tamrin Humaedi ${ }^{2}$ \\ ${ }^{1}$ Jurusan Fisika, FMIPA, Universitas Andalas, Kampus Limau Manis Padang, 25163, \\ ${ }^{2} \mathrm{PT}$. Supreme Energy \\ *devimarisadp@yahoo.co.id
}

\begin{abstract}
ABSTRAK
Penelitian mengenai uji komplesi guna untuk mengetahui karakterisasi sumur dan reservoir panas bumi, antara lain lokasi feed zones dan kontribusinya, injectivity index (II), profil tekanan dan temperatur, jenis fluida, serta potensi produksi sumur telah dilakukan di sumur panas bumi ML-XX Muara Laboh, Solok Selatan. Uji komplesi dilakukan melalui beberapa tahap, dimulai dari PTS injection, multi-rate injectivity test, PT heating-up survey hingga pemodelan sumur. Data dari hasil uji komplesi akan digunakan untuk menghitung estimasi potensi produksi dari sumur tersebut dengan melakukan pemodelan sumur. Hasil dari uji komplesi pada sumur ML-XX menunjukkan adanya 4 lokasi feed zone dengan feed zone utama terletak pada kedalaman 1536 m, lokasi lain terletak pada kedalaman $1617 \mathrm{~m}, 1797 \mathrm{~m}$, dan >1878 m. Feed zone mayor memiliki laju alir massa sebesar $49 \mathrm{~kg} / \mathrm{s}$, kontribusi aliran $60 \%$ dan injectivity index (II) sebesar $9 \mathrm{~kg} / \mathrm{s}$.bara. Untuk estimasi potensi produksi, didapatkan sebesar 8,2 MWe pada tekanan kepala sumur (WHP) 9,2 bara dengan tekanan separasi sebesar 7 bara menggunakan metode Hagedorn-Brown. Sumur ML-XX merupakan sumur satu fasa dengan sistem dominasi air.

Kata kunci: uji komplesi, feed zones, injectivity index, pemodelan sumur
\end{abstract}

\section{ABSTRACT}

The study of completion test in order to determine the characterization of geothermal wells and reservoirs, among locations and contribution of feed zones, injectivity index (II), pressure and temperature profiles, fluid type, and production potential of the well have been done in the geothermal wells ML-XX Muara Laboh, Solok Selatan. Completion test conducted in several sequence. The test starts from PTS injection, multi-rate injectivity test, PT heating-up survey and wellbore modelling. Data of completion test results will be used to calculate the estimation of the production potential of the well by using wellbore modelling. The results of the completion test of $M L-X X$ well indicates the existence of four feed zones locations with major feed zone at $1536 \mathrm{~m}$, another location is at a depth of $1617 \mathrm{~m}, 1797 \mathrm{~m}$ and $>1878 \mathrm{~m}$. Major feed zone has the mass flow rate of $49 \mathrm{~kg} / \mathrm{s}$, the contribution flow of $60 \%$ and injectivity index (II) of $9 \mathrm{~kg} / \mathrm{s}$. bara. To estimate the production potential amounted to 8,2 MWe at wellhead pressure 9,2 bara with separation pressure 7 bara using Hagedorn-Brown method. This well is one phase well with water dominated system.

Keywords: completion test, feed zones, injectivity index, wellbore modelling

\section{PENDAHULUAN}

Kebutuhan akan bahan bakar fosil yang semakin meningkat menyebabkan cadangan bahan bakar tersebut semakin lama semakin menipis. Untuk itu perlu adanya energi baru terbarukan yang dapat mengurangi ketergantungan akan bahan bakar fosil tersebut, salah satunya energi panas bumi atau geothermal. Potensi akan energi panas bumi di Indonesia tersebar di sepanjang jalur ring of fire, oleh karena itu perlu adanya pengembangan akan energi panas bumi tersebut. Pengembangan dapat dilakukan apabila karakterisasi sumur dan reservoir dapat dipahami dengan baik. Hal ini dapat dilakukan dengan melakukan survei, dimulai dari survei geologi, geokimia, geofisika, pengeboran, serta pengukuran dan pengujian sumur (Situmorang, 2012). Pengukuran dan pengujian diawali dengan uji komplesi. Uji komplesi merupakan suatu pengujian sumur yang bertujuan untuk mengetahui karakterisasi sumur dan reservoir di bawah permukaan. Uji komplesi pada umumnya terdiri dari PTS (Pressure, Temperature, Spinner) injection, multi-rate injectivity test, fall-off test dan PT (Pressure, Temperature) heating-up survey. Pada uji komplesi ini, dapat diperoleh informasi seperti karakterisasi feed zone (lokasi, kontribusi aliran, injectivity index/II atau productivity index/PI), jenis reservoir, jenis fluida produksi, temperatur dan tekanan fluida di dalam sumur dan reservoir, kondisi lubang sumur, karakteristik reservoir di sekitar sumur serta kemampuan 
produksi sumur (pemodelan sumur). Gambar 1 menunjukkan rangkaian uji komplesi yang dilakukan setelah pengeboran.

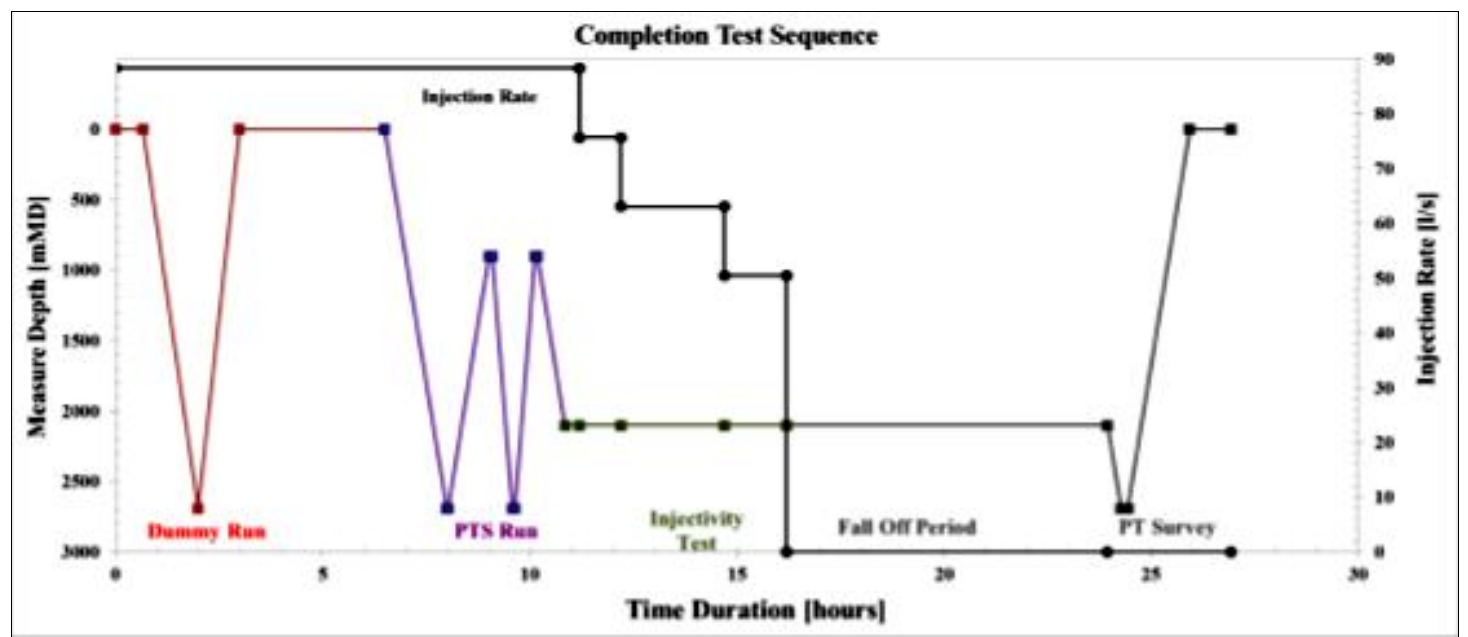

Gambar 1 Rangkaian uji komplesi

(Sumber: Humaedi, 2016)

\section{METODE}

\subsection{PTS Injection}

PTS injection dilakukan untuk mengidentifikasi lokasi feed zone beserta kontribusi alirannya. Data yang terekam pada saat PTS injection adalah data tekanan, temperatur dan frekuensi putaran spinner. Frekuensi putaran spinner (rotation per second atau RPS) dan kecepatan kabel (cable velocity atau CV) dihitung dan dikonversi menjadi kecepatan aliran fluida (V) (Lette, 2013). Data kecepatan aliran fluida mempengaruhi nilai laju alir massa (M), dari nilai laju alir massa dapat ditentukan kontribusi aliran dari setiap feed zone yang didapatkan.

\subsection{Multi-rate Injectivity Test}

Multi-rate injectivity test merupakan suatu tes yang dilakukan untuk mengetahui transien tekanan dengan menggunakan laju injeksi yang berbeda-beda hingga didapatkan tekanan yang stabil. Efek dari perubahan laju injeksi dapat dimonitor dengan cara mencari hubungan laju injeksi dan tekanan yang stabil sehingga dapat diperoleh besarnya injectivity index (II). Setelah nilai II total didapatkan, maka nilai II per feed zone dapat ditentukan berdasarkan kontribusi aliran yang telah didapatkan sebelumnya pada PTS injection. Tes ini dilakukan pada suatu kedalaman yakni pada kedalaman feed zone utama, dan test ini bertujuan untuk mengetahui kualitas dari masing - masing feed zone yang didapatkan.

\subsection{PT Heating-up Survey}

Setelah uji komplesi selesai, penginjeksian air dihentikan dengan mematikan pompa. Sumur relatif dingin setelah uji komplesi. Uji produksi tidak dilakukan pada sumur dingin, karena aliran fluida panas melalui casing yang dingin dapat menyebabkan terjadinya kerusakan pada casing. Setelah uji komplesi biasanya sumur ditutup selama beberapa waktu agar menjadi panas sebelum sumur tersebut diuji kemampuan produksinya. Tekanan dan temperatur di dalam sumur diukur pada interval-interval waktu tertentu. Pengukuran biasanya dilakukan pada hari ke $1,2,4,7,14,28$, dan 42 tetapi bila diperlukan profil temperatur yang lebih rinci maka uji panas dapat diteruskan. Lama waktu pemanasan bervariasi, mulai dari hanya beberapa jam hingga beberapa bulan sampai kondisi tekanan dan temperatur di dalam sumur stabil. Untuk mendapatkan informasi yang baik, pengukuran tekanan dan temperatur (PT) sebaiknya dilakukan beberapa kali selama sumur dipanaskan hingga temperaturnya stabil (Saptadji, 2005) 


\subsection{Estimasi Potensi Produksi}

Data dari hasil uji komplesi digunakan untuk menghitung estimasi potensi produksi dari sumur tersebut dengan melakukan pemodelan sumur. Pemodelan sumur dilakukan dengan cara menginputkan data geometri sumur, properti reservoir dan parameter perhitungan yang telah didapatkan dari hasil pengolahan data uji komplesi.

\section{HASIL DAN DISKUSI}

\subsection{PTS Injection}

Gambar 2 merupakan grafik hubungan nilai tekanan dan temperatur terhadap kedalaman pada saat pengukuran sumur (logging). Berdasarkan Gambar 2, dapat dilihat bahwa temperatur di dalam sumur tidak sampai $30^{\circ} \mathrm{C}$, hal ini karena yang diinjeksikan ke dalam sumur adalah air dingin dingin, sehingga tidak mungkin temperaturnya mencapai temperatur didih. Untuk tekanan, apabila gradien tekanan besar maka jenis fluida yang teridentifikasi adalah air (liquid), apabila gradien tekanan kecil, maka jenis fluida yang teridentifikasi adalah kolom gas.

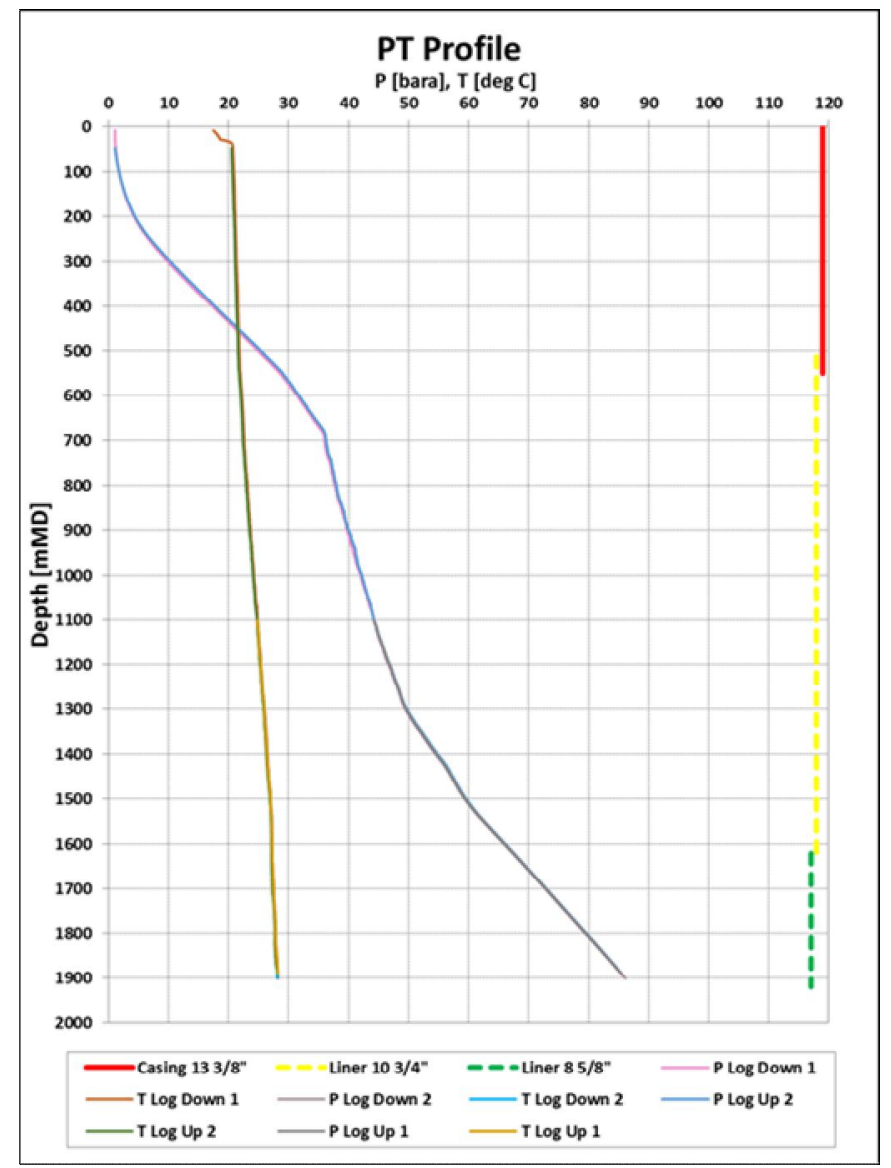

Gambar 2 Profil tekanan-temperatur

Untuk data frekuensi putaran spinner (rotation per second atau RPS) terlihat pada Gambar 3. Pada Gambar terlihat respon spinner di sepanjang sumur, pada kedalaman 0-1500 m grafik spinnernya terlihat kacau, karena pada kedalaman 0-690 m fluidanya masih air namun di kolom tersebut masih ada udaranya, untuk kedalaman 700-1500 m terdapat kolom gas, sehingga pada kedalaman 0-1500 m profil RPS nya tidak dapat dianalisa. Pada kedalaman 1500-1900 m, casingnya sudah terisi $100 \%$ air, sehingga respon spinnernya baik dan dapat dianalisa. Oleh karena itu, penelitian hanya akan difokuskan pada kedalaman $1500 \mathrm{~m}$ hingga $1900 \mathrm{~m}$. Perubahan pada spinner mengidentifikasikan adanya lokasi feed zone, pada Gambar teridentifikasi adanya tiga lokasi feed zone yakni pada kedalaman $1536 \mathrm{~m}, 1797 \mathrm{~m}$ dan $1878 \mathrm{~m}$, namun hal itu hanya estimasi awal saja yang nantinya akan dikonfirmasi melalui data kecepatan aliran fluida dan laju alir massa. 


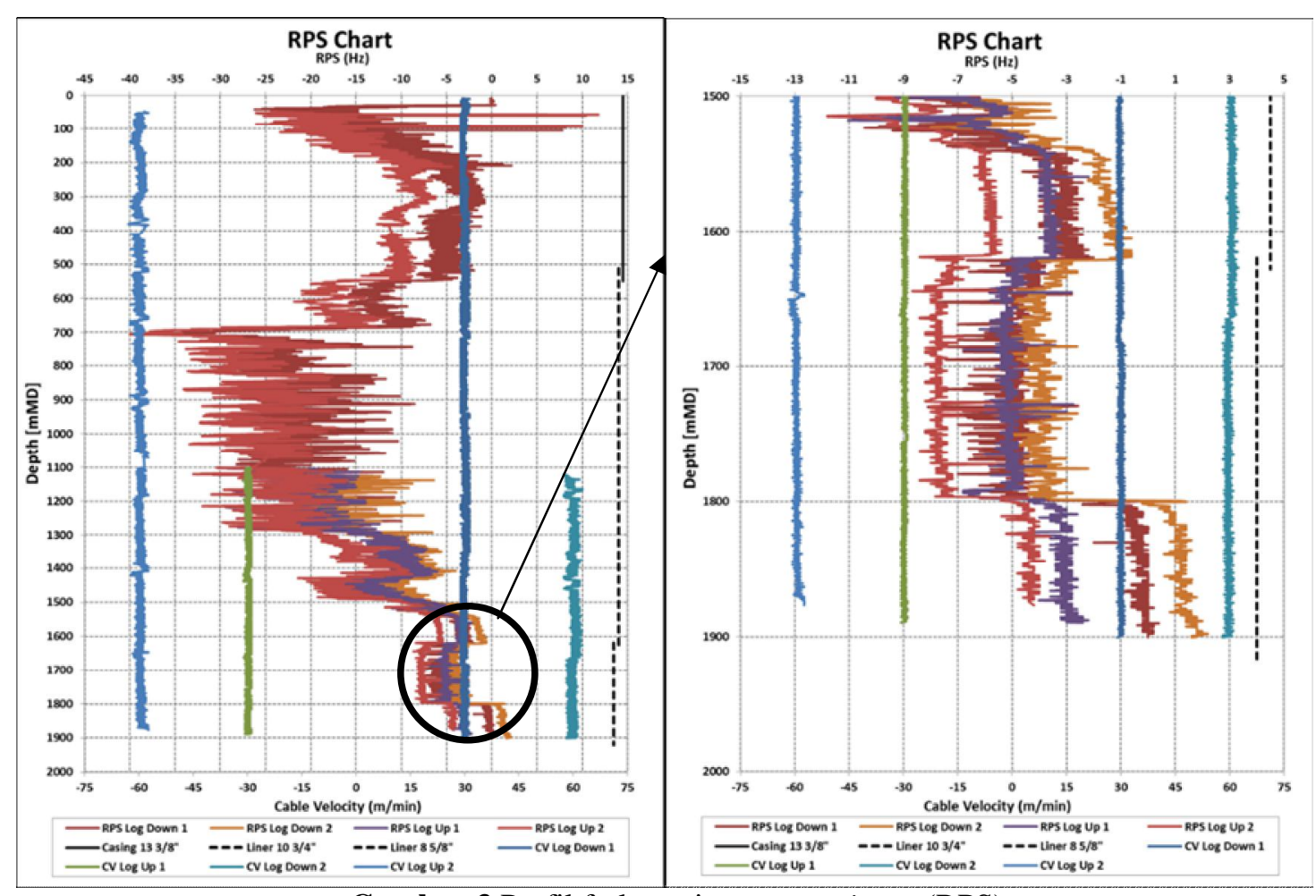

Gambar 3 Profil frekuensi putaran spinner (RPS)

Frekuensi putaran spinner (RPS) dikonversi dan dihitung bersama dengan kecepatan kabel (CV) untuk memperoleh nilai dari kecepatan aliran fluida, kemudian laju alir massa dapat ditentukan setelah diperolehnya nilai kecepatan aliran fluida karena memiliki pengaruh untuk perhitungan nilai laju alir massa. Gambar 4 menunjukkan data dari kecepatan aliran fluida dan laju alir massa.

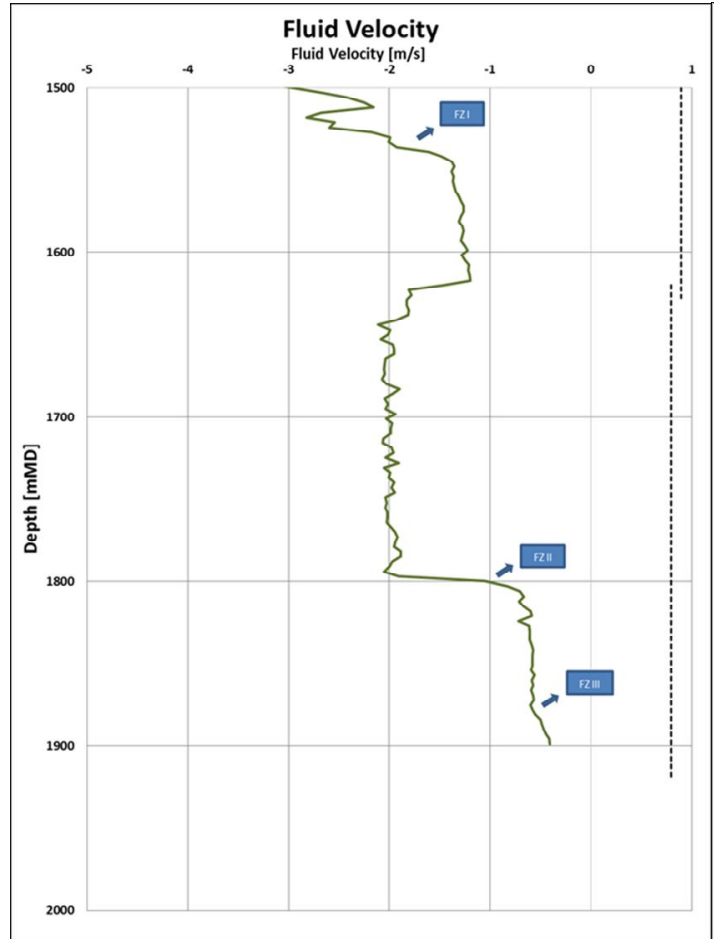

(a)

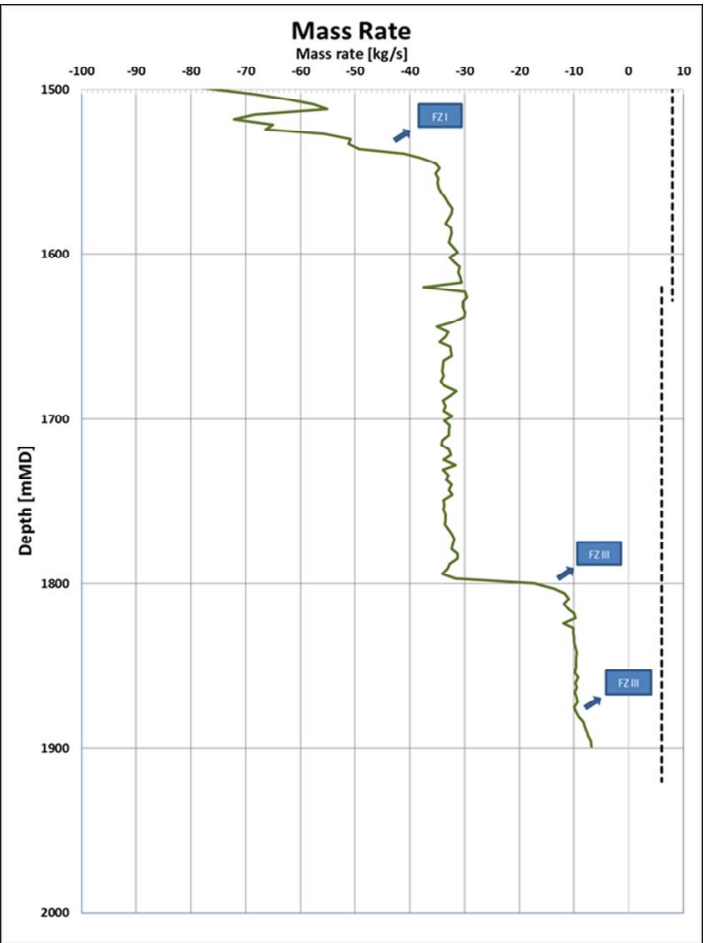

(b)

Gambar 4 Profil kecepatan aliran fluida (a) dan laju alir massa (b) 
Perubahan nilai dari kecepatan aliran fluida mengidentifikasikan adanya lokasi feed zone. Pada Gambar 4a terlihat adanya tiga lokasi feed zone yang teridentifikasi pada sumur tersebut, yakni pada kedalaman yang sama dengan yang teridentifikasi pada profil RPS. Pada Gambar 4b terlihat perubahan dari nilai laju alir massa, hal ini menunjukkan bahwa pada perubahan tersebut terdapat lokasi feed zone. Lokasi feed zone yang didapatkan sama dengan lokasi feed zone yang teridentifikasi pada profil RPS dan kecepatan aliran fluida. Setelah lokasi feed zone diperoleh, maka kontribusi aliran dari masing-masing feed zone tersebut dapat ditentukan. Kontribusi dari masing-masing feed zone terlihat pada Tabel 1.

Tabel 1 Kontribusi aliran setiap feed zone

\begin{tabular}{lccc}
\hline Feed Zone & Depth [mMD] & $\begin{array}{c}\text { Mass Rate } \\
{[\mathbf{k g} / \mathbf{s}]}\end{array}$ & $\begin{array}{c}\text { Kontribusi } \\
{[\%]}\end{array}$ \\
\hline I & 1536 & 49 & 60 \\
II & 1797 & 23 & 28 \\
III & 1878 & 10 & 12 \\
\hline
\end{tabular}

Dari hasil perhitungan tersebut, maka feed zone I bertindak sebagai feed zone utama karena memiliki kontribusi aliran terbesar yakni $60 \%$ dengan laju alir massa sebesar $49 \mathrm{~kg} / \mathrm{s}$.

\subsection{Multi-rate Injectivity Test}

Gambar 5a menunjukkan transien tekanan dengan menggunakan laju injeksi yang berbeda-beda hingga didapatkan tekanan yang stabil, tekanan yang stabil tersebut kemudian diplot terhadap masing-masing laju injeksi yang diberikan seperti yang terlihat pada Gambar $5 \mathrm{~b}$.

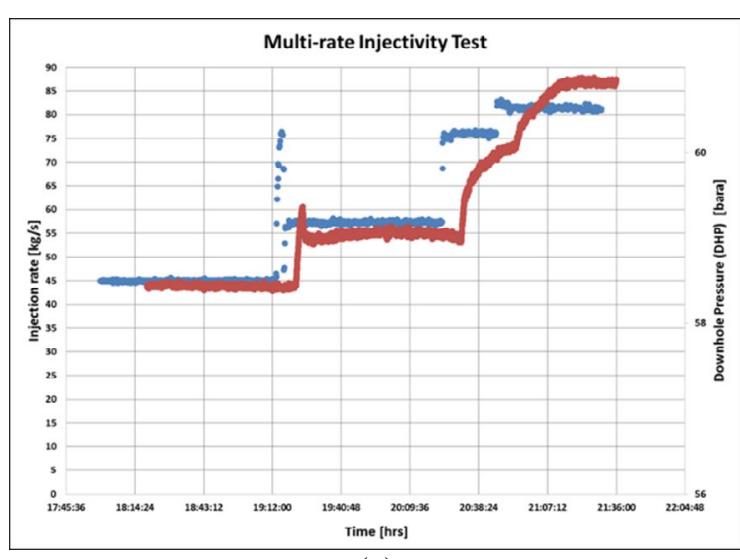

(a)

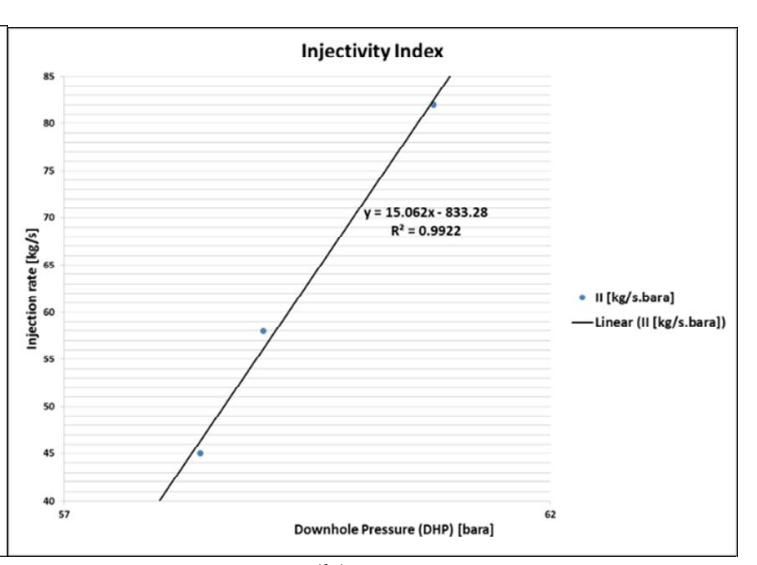

(b)

Gambar 5 Perhitungan uji injeksi.

Nilai injectivity index (II) yang didapatkan dari hasil plot antara laju injeksi dengan tekanan yang stabil digunakan untuk mencari injectivity index (II) pada setiap feed zone, sehingga didapatkan hasil seperti yang ditunjukkan pada Tabel 2.

Tabel 2 Injectivity index (II)

\begin{tabular}{cccccc}
\hline Feed Zones & Depth [mMD] & $\begin{array}{c}\text { Mass Rate } \\
{[\mathbf{k g} / \mathbf{s}]}\end{array}$ & $\begin{array}{c}\text { Kontribusi } \\
{[\%]}\end{array}$ & $\begin{array}{c}\text { II } \\
{[\mathbf{k g} / \mathbf{s} . \mathbf{b a r a}]}\end{array}$ & Remarks \\
\hline I & 1536 & 49 & 60 & 9,0 & Outflow \\
II & 1797 & 23 & 28 & 4,2 & Outflow \\
III & 1878 & 10 & 12 & 1,8 & Outflow \\
\hline
\end{tabular}

Dari hasil perhitungan tersebut, maka feed zone I yang bertindak sebagai feed zone utama juga memiliki nilai injectivity index (II) terbesar yakni $9 \mathrm{~kg} / \mathrm{s}$.bara. 


\subsection{PT Heating-up Survey}

Gambar 6a dan 6b menunjukkan profil dari temperatur dan tekanan di sepanjang sumur dalam keadaan ditutup (shut-in). Data temperatur (Gambar 6a) mengindikasikan kehadiran feed zone minor pada kedalaman 1617 m yang tidak terdeteksi pada data PTS injection sebelumnya, sehingga lokasi feed zone yang terdeteksi pada sumur ini menjadi 4 lokasi feed zone dengan feed zone I bertindak sebagai feed zone utama (Tabel 3). Pada data tekanan (Gambar 6b) diperoleh pivot point atau disebut juga dengan sebagai tekanan reservoir dan juga menjadi acuan untuk mendapatkan tekanan reservoir di sepanjang sumur, hal ini terlihat pada Gambar 7.

Tabel 3 Perkiraan lokasi feed zones beserta kontribusi dan nilai II

\begin{tabular}{cccccc}
\hline Feed Zones & Depth [mMD] & $\begin{array}{c}\text { Mass Rate } \\
{[\mathbf{k g} / \mathbf{s}]}\end{array}$ & $\begin{array}{c}\text { Kontribusi } \\
{[\%]}\end{array}$ & $\begin{array}{c}\text { II } \\
{[\mathbf{k g} / \mathbf{s . b a r a}]}\end{array}$ & Remarks \\
\hline I & 1536 & 49 & 60 & 9,0 & Outflow \\
II & 1797 & 23 & 28 & 4,2 & Outflow \\
III & 1878 & 10 & 12 & 1,8 & Outflow \\
IV & 1878 & 10 & 12 & 1,8 & Outflow \\
\hline
\end{tabular}

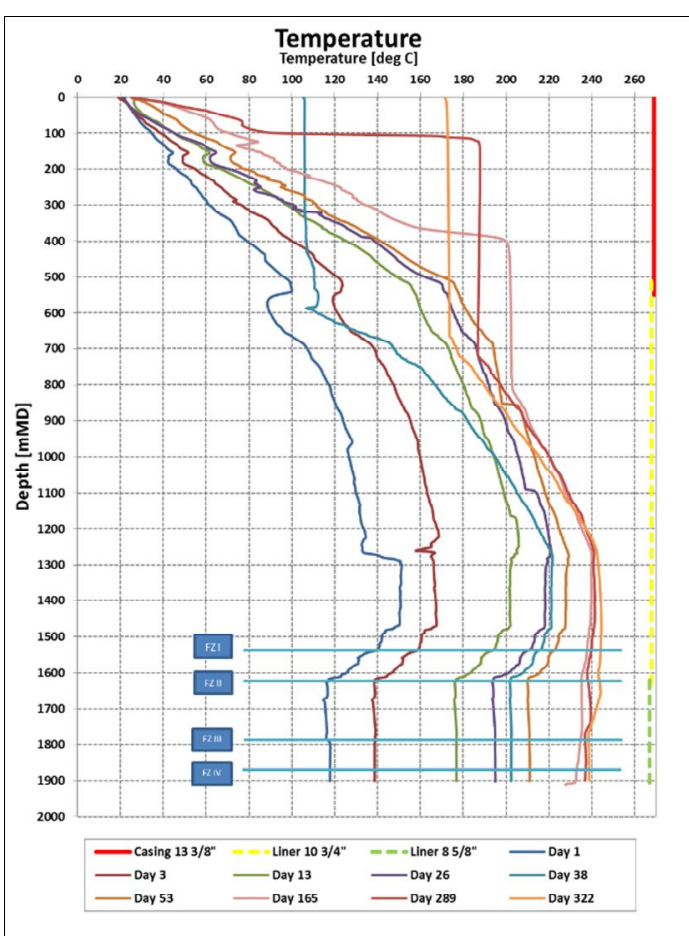

(a)

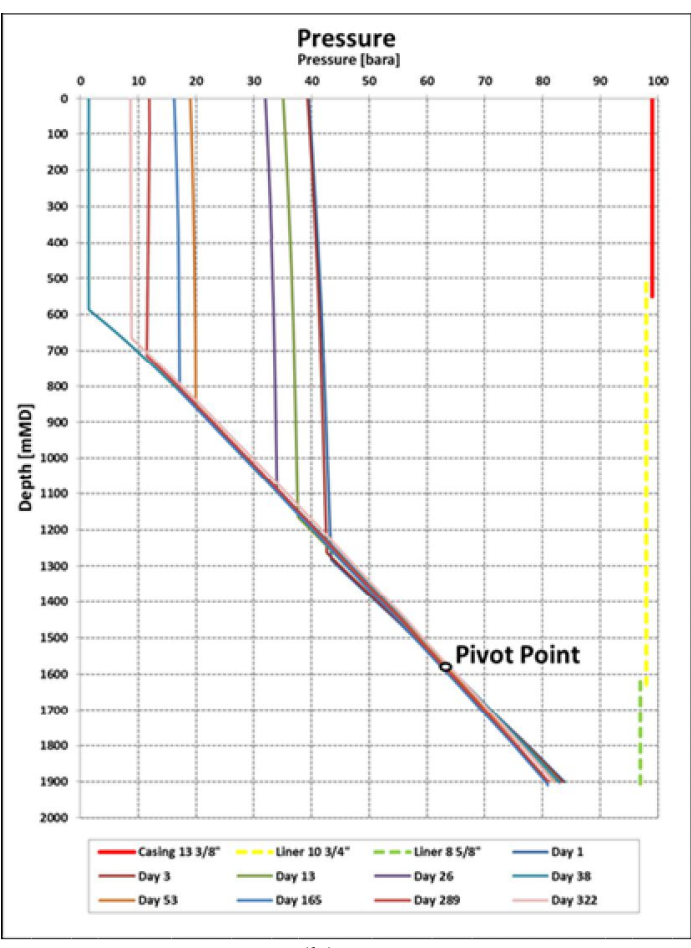

(b)

Gambar 6 (a) profil temperatur, (b) profil tekanan 


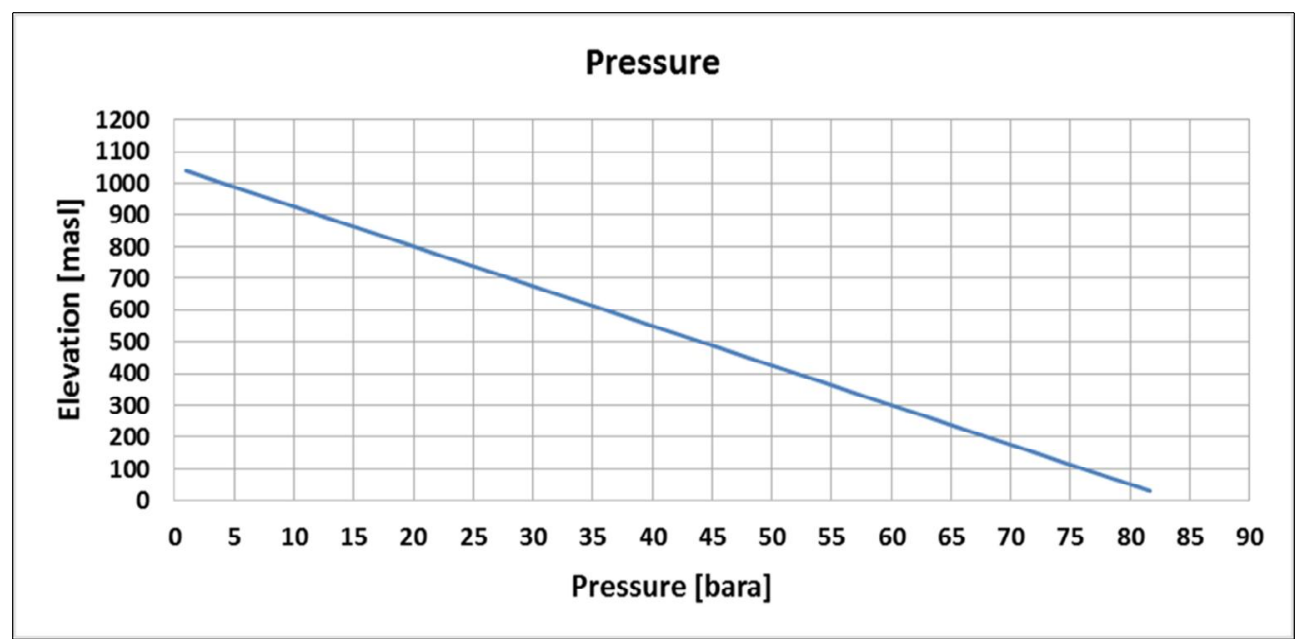

Gambar 7 Distribusi tekanan reservoir di sepanjang sumur

Untuk menentukan jenis fluida yang terdapat didalam sumur, dapat dilihat pada grafik Boiling Point with Depth (BPD) pada Gambar 8. Pada Gambar terlihat bahwa jenis fluida yang terdapat didalam sumur adalah fluida satu fasa berjenis air (liquid), hal ini terlihat dari temperatur sumur yang berada dibawah temperatur saturasi.

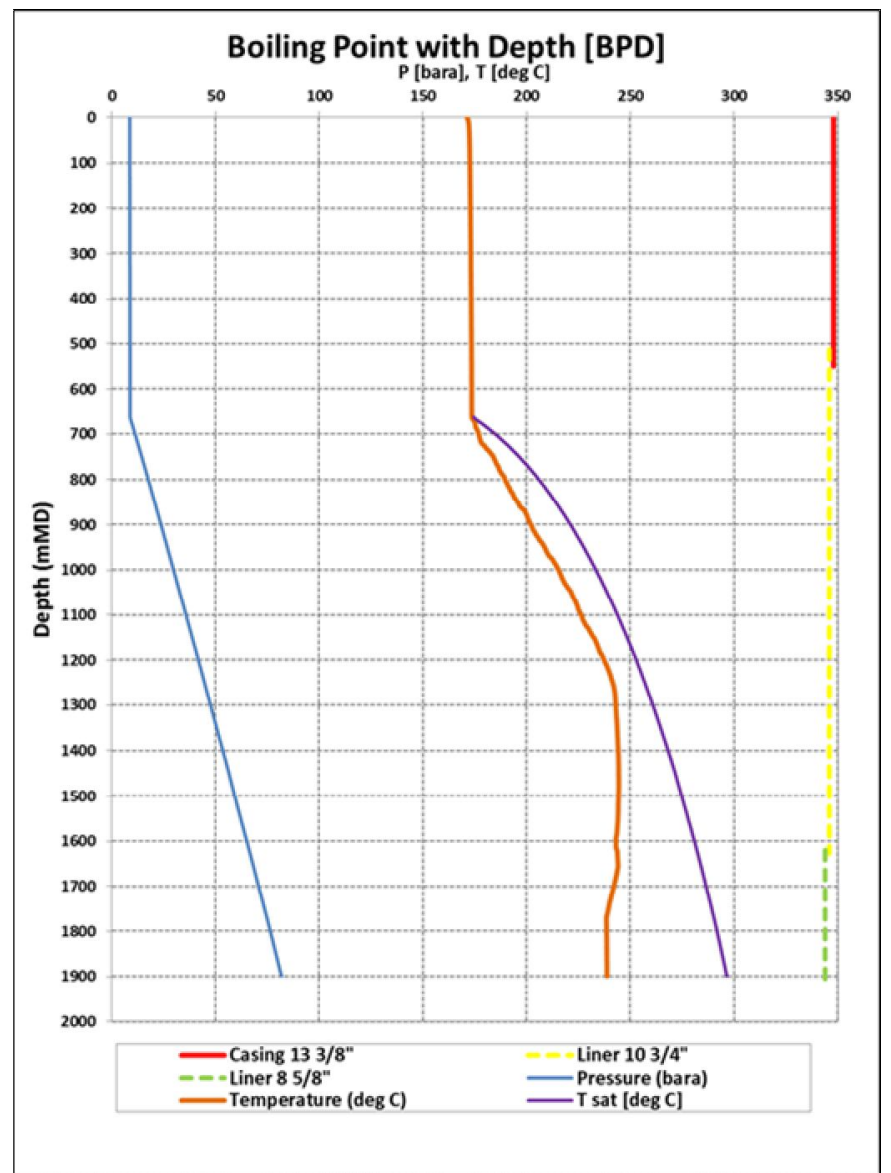

Gambar 8 Boiling Point with Depth (BPD)

\subsection{Estimasi Potensi Produksi}

Estimasi potensi produksi didapatkan dari pemodelan sumur dengan mengggunakan metode Hagedorn-Brown. Tabel 4 menunjukkan hasil dari pemodelan dan pengolahan data sumur hingga didapatkan estimasi potensi produksi sumur. 
Tabel 4 Hasil output test dan estimasi kapasitas produksi

\begin{tabular}{ccccccc}
\hline $\begin{array}{c}\text { WHP } \\
{[\mathbf{b a r a}]}\end{array}$ & Mtot $[\mathbf{k g} / \mathbf{s}]$ & $\begin{array}{c}\text { Enthalpy } \\
{[\mathbf{k J} / \mathbf{k g}]}\end{array}$ & Fraksi & $\begin{array}{c}\text { Msteam } \\
{[\mathbf{k g} / \mathbf{s}]}\end{array}$ & $\begin{array}{c}\text { Mbrine } \\
{[\mathbf{k g} / \mathbf{s}]}\end{array}$ & W [MWe] \\
\hline 9,2 & 122,6 & 1034,1 & 0,2 & 20,0 & 102,6 & 8,2 \\
10,7 & 108,5 & 1034,6 & 0,2 & 17,7 & 90,8 & 7,2 \\
11,9 & 94,4 & 1034,8 & 0,2 & 15,4 & 79,0 & 6,3 \\
12,9 & 80,4 & 1034,9 & 0,2 & 13,1 & 67,2 & 5,4 \\
13,8 & 66,4 & 1034,9 & 0,2 & 10,8 & 55,5 & 4,4 \\
14,7 & 52,4 & 1034,8 & 0,2 & 8,6 & 43,8 & 3,5 \\
15,5 & 38,4 & 1034,5 & 0,2 & 6,3 & 32,1 & 2,6 \\
16,2 & 24,4 & 1034,0 & 0,2 & 4,0 & 20,4 & 1,6 \\
16,5 & 10,5 & 1032,0 & 0,2 & 1,7 & 8,8 & 0,7 \\
\hline
\end{tabular}

Dari hasil output test pada Tabel 4 dapat terlihat bahwa apabila sumur dibuka dengan tekanan kepala sumur (WHP) sebesar 9,19 bara, maka estimasi potensi sumur yang didapatkan adalah sebesar 8,16 MWe dan seterusnya. Hubungan antar WHP dengan estimasi potensi produksi sumur (daya listrik) dapat terlihat pada Gambar 9.

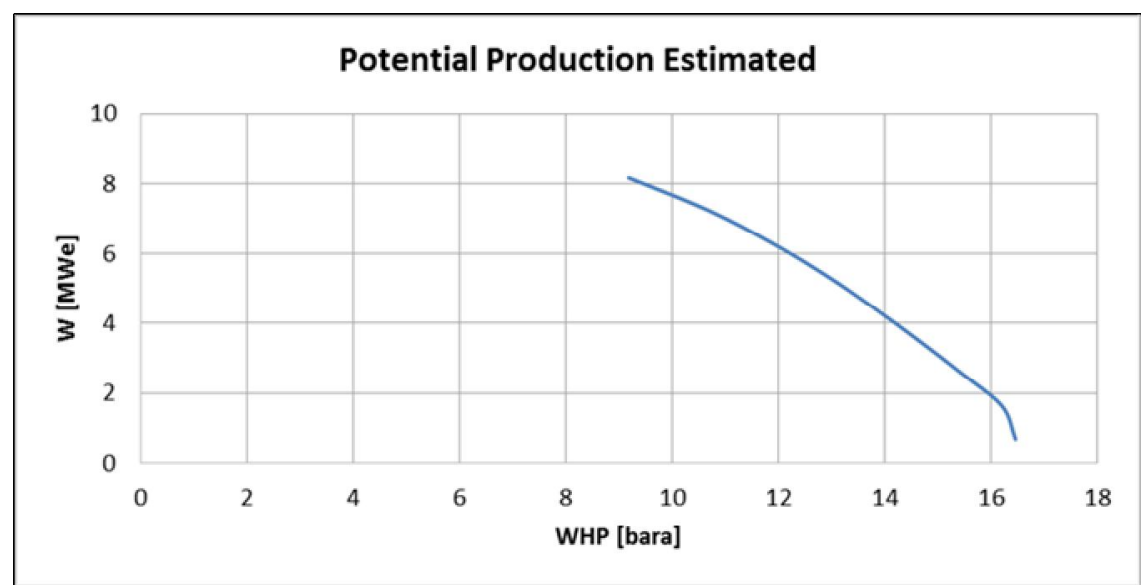

Gambar 9 Hubungan WHP dan estimasi potensi produksi

Pada Gambar 9, terlihat hubungan berbanding terbalik antara WHP dan estimasi potensi produksi, semakin besar nilai WHP yang diberikan maka semakin kecil estimasi potensi produksi (daya listrik) yang dihasilkan.

\section{KESIMPULAN}

Hasil dari uji komplesi pada sumur ML-XX menunjukkan adanya 4 lokasi feed zones dengan feed zone utama terletak pada kedalaman $1536 \mathrm{~m}$, lokasi lain terletak pada kedalaman $1617 \mathrm{~m}, 1797 \mathrm{~m}$, dan >1878 m. Feed zone utama memiliki laju alir massa sebesar $49 \mathrm{~kg} / \mathrm{s}$, kontribusi aliran $60 \%$ dan injectivity index (II) sebesar $9 \mathrm{~kg} / \mathrm{s}$.bara. Untuk estimasi potensi produksi, didapatkan sebesar 8,2 MWe pada tekanan kepala sumur (WHP) 9,2 bara dengan tekanan separasi sebesar 7 bara menggunakan metode Hagedorn-Brown. Sumur ML-XX merupakan sumur satu fasa dengan sistem dominasi air.

\section{UCAPAN TERIMA KASIH}

Penulis mengucapkan terima kasih kepada PT. Supreme Energy Muara Laboh (SEML) yang telah memberikan dukungan penuh dalam penelitian ini.

\section{DAFTAR PUSTAKA}

Humaedi, M.T. dkk., 2016, A Comprehensive Well Testing Implementation during Exploration Phase in Rantau Dedap (Indonesia), PROCEEDINGS, 41st Workshop on Geothermal

Reservoir Engineering, February 22-24, Stanford University, Stanford, California. 
Lette, S.C., 2013, Menentukan Letak Feed Zone dan Parameter Aliran menggunakan PressureTemparture-Spinner (PTS) pada Sumur "S" di Lapangan Wayang Windu, Skripsi, Teknik Perminyakan, UPN Veteran Yogyakarta, Yogyakarta.

Saptadji, N.M., 2005, Energi Panas Bumi (Geothermal Energy), Institut Teknologi Bandung, Bandung.

Situmorang, J., 2012, Pengembangan Program Komputer "PTS3" Untuk Karakterisasi Zona Permeabel dan Aliran Fluida dalam Sumur Panas Bumi berdasarkan Survei PTS, Tesis, Teknik Panas Bumi, Institut Teknologi Bandung, Bandung. 